\title{
Critical Reflexivity in Political Ecology Research: How can the Covid-19 Pandemic Transform us Into Better Researchers?
}

\begin{abstract}
Noémi Gonda *, Stephanie Leder, Marien González-Hidalgo, Linley Chiwona-Karltun, Arvid Stiernström, Flora Hajdu, Klara Fischer, Ildikó Asztalos Morell, Alin Kadfak and Anna Arvidsson
\end{abstract}

Department of Urban and Rural Development, Swedish University of Agricultural Sciences, Uppsala, Sweden

It is not just the world but our ways of producing knowledge that are in crisis. The Covid-19 pandemic has exposed our interconnected vulnerabilities in ways never seen before while underscoring the need for emancipation in particular from the hegemonic knowledge politics that underpin "business-as-usual" academic research that have both contributed to and failed to address the systemic challenges laid bare by the pandemic. Political ecologists tasked with knowledge generation on vulnerabilities and their underlying power processes are particularly well placed to envision such emancipatory processes. While pausing physically due to travel restrictions, as researchers in political ecology and rural development at the same university department, we want to make a stop to radically rethink our intellectual engagements. In this article, we aim to uncover "sanitized" aspects of research encounters, and theorize on the basis of anecdotes, feelings and informal discussions - "data" that is often left behind in fieldwork notes and personal diaries of researchers - , the ways in which our own research practices hamper or can be conducive to emancipation in times of multiple interconnected health, political, social, and environmental crises. We do so through affective autoethnography and resonances on our research encounters during the pandemic: with people living in Swedish Sapmi, with African students in our own "Global North" university department and with research partners in Nepal. We use a threefold focus on interconnectedness, uncertainty and challenging hegemonic knowledge politics as our analytical framework. We argue that acknowledging the roles of emotions and affect can 1) help embrace interconnectedness in research encounters; 2) enable us to work with uncertainty rather than "hard facts" in knowledge production processes; and 3) contribute to challenging hegemonic knowledge production. Opening up for emotions in research helps us to embrace the relational character of vulnerability as a pathway to democratizing power relations and to move away from its oppressive and colonial modes still present in universities and research centers. Our aim is to contribute to envisioning post-Covid-19 political ecology and rural development research that is critically reflexive and that contributes to the emergence of a new ethics of producing knowledge.

Keywords: reflexivity, political ecology, COVID-19, vulnerability, knowledge politics, affect, emotions, uncertainty 
Historically, pandemics have forced humans to break with the past and imagine their world anew. This one is no different. It is a portal, a gateway between one world and the next. We can choose to walk through it, dragging the carcasses of our prejudice and hatred, our avarice, our data banks and dead ideas, our dead rivers and smoky skies behind us. Or we can walk through lightly, with little luggage, ready to imagine another world. And ready to fight for it.

(Roy, 2020)

\section{INTRODUCTION}

It is not just the world but our ways of producing knowledge that are in crisis. The Covid-19 pandemic, or the Virocene - this "period in which viral activity has evolved as a dominant force shaping human-nature relations" (Fernando, 2020a, 686) prompts us to confront and question our current world order. As such, the Virocene "exposes the vulnerabilities in, and moral and pragmatic failures of social and ecological systems in safeguarding both social and ecological wellbeing" (Fernando, 2020a, 687), while underscoring the need for emancipation in particular from the hegemonic knowledge politics that have both contributed to and failed to address the systemic challenges laid bare by the pandemic.

The pandemic has more than ever made visible what we understand as the crisis of hegemonic knowledge politics: the counter-hegemonic challenges faced by decolonial, feminist and indigenous scholarships. Among the concrete manifestations of this crisis, the pandemic has exacerbated the digital divide in higher education with consequences for counter-hegemonic sites of knowledge production, as students, teachers and researchers struggle to access funds, computers, internet, laboratories, and institutional support, particularly in the Global South. Additional care responsibilities have unequally impacted female and minority scholars (Pinho-Gomes et al., 2020; Deryugina et al., 2021). Many early career scholars with insecure contracts have lost their jobs (Levine and Rathmell, 2020; Herman et al., 2021). Halted research projects have jeopardized the livelihoods of research assistants and translators in the Global South. In general, in the Global North, scholarly and everyday attention has been refocused on a privileged "we" or the "center" to which "we" belong. These are places where health care is broadly functioning and for which vaccines are developed, while the "periphery," already distanced epistemologically, has suddenly also become far-away geographical places due to travel restrictions.

As researchers in political ecology and rural development at the same university department, we wanted to make use of this moment of involuntary break in fieldwork, to reflect over our own roles and actions as researchers in this moment of heightened vulnerability. We do not only pause physically due to travel restrictions but also intellectually to radically rethink our intellectual engagements: this is for us a moment of no return. Political ecology scholarship has been central for research on vulnerabilities and their underlying power processes. Therefore, we suggest it is the ideal arena for a deeper interrogation about how our own knowledge production both contributes to the vulnerability of others, and makes ourselves vulnerables. To counter the reproduction of unequal power relations in research processes, reflection and dialogue are necessary transformative practices (Freire, 1996); yet, this is not a common endeavor in our academic world. We argue that, as researchers, we need to reflect critically and constructively on the ways in which our own practices hamper or can be conducive to emancipation in times of multiple interconnected health, political, social, and environmental crises. Only by better understanding how our own research practices sustain hegemonic knowledge politics, will we be able to truly envision and engage with emancipation.

In what follows, we first present our conceptual and methodological approaches. We then share three vignettes of self-reflection and resonances on research practices during the Covid-19 pandemic. In the discussion, we argue that engaging with affect and emotions in knowledge-making processes as well as with relational vulnerability in research encounters can help go beyond hegemonic knowledge politics in academia.

\section{RECENTERING AFFECT AND EMOTIONS TO ENGAGE WITH THE CHALLENGES HIGHLIGHTED BY THE PANDEMIC: INTERCONNECTEDNESS, UNCERTAINTY AND THE CRISIS OF HEGEMONIC KNOWLEDGE POLITICS}

In this section, we argue that the pandemic has highlighted that affect and emotions must become central in knowledge production processes. This starting point has made us come together here and now to collectively rethink our ways of generating knowledge through our research encounters.

Our exercise is first and foremost intellectual, yet it has emancipatory potentials: we start from the idea that imagination and hope are already something radical (Freire, 1996; hooks, 2003). Indeed, a "critical consciousness" of individual experiences and oppressive social contexts can become a basis for empathy and action to overcome oppressive conditions. From reflection on the causes of oppression "will come (...) necessary engagement in the struggle for (...) liberation" (Freire, 1996, 30). The type of emancipation that we envision needs to give more meaning to affect and emotions as we are not looking for emancipation as an end-point, but rather as a process. As we explain below, affect and emotions can be drivers for agency and empowerment. Empowerment is best understood as a continuous performance (Butler, 1990) and through cultivating empathy and "critical consciousness," "la conscientização," (Freire, 1996, 
16), not something that can be indefinitely "achieved" with "better" and more "precise" data and scenarios.

\section{Affect and Emotions}

Focusing on affect allows us to think through the emotional, experiential, and embodied relations that underpin knowledge claims, and can trigger emancipation (Anderson, 2012). We do not aim at theorizing affect but we understand affect as what makes the socio-material hold together or fall apart (Müller, 2015). Especially useful for our discussion on research encounters is understanding how affective encounters help to shape collectives (Singh, 2017; Nightingale, 2019). We start from the premise that emotions, affect and affective relations will help us envision the types of emancipatory research practices needed to confront the crisis we are currently in. Emotions, affect, and affective relations can, for example, help us to think about how anger, indignation, empathy or love and our affective relations with differently situated others bond us into a group and can lead us to work more productively with the fact that emotions and affect determine the politics of knowledge creation (Anderson, 2012). That is, affect and emotions understood as ways of learning, experiencing and responding to changes help shift attention from individual responsibilities to collective ones.

In the three sub-sections that follow, we explain how the pandemic has magnified how acknowledging the roles of emotions and affect 1) can help embrace interconnectedness in research encounters; 2) enables working with uncertainty rather than "hard facts" in knowledge production processes; 3 ) contributes to challenging hegemonic knowledge production. This threefold focus constitutes the analytical framework for this paper.

\section{Interconnectedness}

Affective relations are the cement that holds together the commonness of life (Pile, 2010). These relations or interconnectedness have become more apparent than ever under the pandemic. Bolivian anarcho-feminist thinker Maria Galindo (2020) suggests that we all have coronavirus even if we have not been contaminated in our individual bodies: the politics of pandemic management has permeated our everyday lives from its global (Oldekop et al., 2020) to its most intimate spheres. Interconnectedness, as we understand it, does not erase inequalities and injustices: we are still aware of the fact that those who are seen as "disposable," subaltern, black, indigenous and peasant peoples, undocumented migrants and workers, care providers, among others, are the ones unequally bearing the burden and brunt of this pandemic (Dyer, 2020; Mbembe, 2020; Menton et al., 2021).

In addition to being and performing physical bodies that are more or less vulnerable to the virus in a particular place and time, the pandemic has brought to the fore how vulnerabilities are constituted affectively through relations. The pandemic has highlighted how vulnerability is not just an outcome of the interaction between factors often understood as external, exogenous and structural (like the virus' biological features, or food insecurity) and bodily susceptibilities (such as high blood pressure or diabetes). Vulnerability should not be considered as an attribute that characterizes individuals or groups of people. Instead, the pandemic has brought to the fore the relational character of vulnerability as the ability to affect and of being affected (Butler, 1997; Tschakert and Tuana, 2013): vulnerability is a process and a state that changes over time and context. In this understanding, vulnerability is created in relations through connections. Vulnerability is a process of becoming: we become vulnerable as we enter in contact with others, both at the physical and the emotional level.

This relational and affective understanding of vulnerability has important consequences for how to conceptualize emancipation. For us, for being able to envision emancipation, research needs to focus on the relations through which transformation happens or, to the contrary, through which the status quo is maintained. Emancipation is thus the processes through which radical changes come about.

\section{Uncertainty}

Affect theory is useful for drawing attention to the uncertain, random or "aleatory dynamics of lived experience" (Anderson, 2012,18 ) as ways of knowing, but also ways of relating. Focusing on affective processes helps us to better understand the relations that underpin research processes as well as their unpredictable characteristics. These characteristics require us to reflect on our own research practices: how to avoid falling into the trap of the constant pressure for finding "hard," "more," and "better" data? How to better engage with the unintended oppressive and exclusionary consequences of our research practices initially, and maybe naively, aimed at producing emancipatory knowledge? And if we do so, how can this help us to envision an emancipatory scholarship that has the ambition to contribute to building just and sustainable socio-environmental relations?

We wish to practically embrace and bear the consequences of the fact that "the only certainty is uncertainty" (Welsh, 2014, 15), as made exceptionally visible by the pandemic. Uncertainty about the future in the context of the pandemic pushes us to stop and reflect as usually we tend to be engaged in a competitive race for more and "better" data to support our research findings and comply with our institutions' and funders' expectations. The uncertainty and unknowability about the future of our world order that the pandemic has amplified, provides an ideal proxy for the context in which future political ecology research has to be imagined and carried through. As it is widely acknowledged in research engaging with societal transformations, transformative and emancipatory processes must disrupt current pathways yet, such disruptions are not fully controllable or predictable (e.g., Feola, 2015; Stirling, 2015; Patterson et al., 2017; Blythe et al., 2018; Scoones et al., 2020; Scoones and Stirling, 2020).

However, when such research is mobilized for the sake of tackling societal problems, for example regarding climate change, most efforts focus on trying to control transformation as well as the knowledge about it (promoting for example technical fixes) but avoiding debates both on the possibilities for radical transformations and the constant reproduction of hegemonic power processes (Eriksen et al., 2015). Similarly, from what we have seen so far, the type of demands for knowledge generation about the pandemic follow largely in the trajectory of wanting to 
control transformation (e.g., what are its future scenarios and possible economic impacts?), striving to avoid, not only inconsistencies, but also the unknown. To face the fears of uncertainty, the purported efficacy of quantitative research and generating "hard" data such as statistics and models seems to override what experiential knowledge could offer to tackle the pandemic. For example, while since 2020 the way scientists have been researching the virus and developing vaccines is unprecedented, overall, there has yet been less attention given to academic and activist debates about the need for more systematic and long-term changes in our lives, including the need for rethinking our ways of living in common. Crises situations such as the pandemic put extra-pressure on policymakers to take swift and informed decisions. Due to competing views and public pressure "the quantitative framing and false certainties of a model are appealing, and caveats are easily pushed aside" (Leach et al., 2021, 5). Embracing the unknown and the uncertain would instead allow us to think and act in new nonnormative ways, in order to accommodate affective processes that we accept are inherently unpredictable.

Our efforts to re-think knowledge production practices in academia in ways that embrace rather than eradicate uncertainty are part of broader initiatives to re-think the politics of transformation (Scoones, 2016) and the politics of uncertainty (Scoones and Stirling, 2020) beyond rendering them technical and techno-administrative issues (Ferguson, 1990; Li, 2007). To achieve this, knowledge politics have to be understood in relation to hegemonic regimes of accumulation and truth (Scoones, 2016): whose interests is it to hide certain realities and silence uncertainties? Only by engaging with these questions will we be able to go beyond technocratic and marginalizing discussions of why development projects and policies constantly fail (Paranage, 2019). Indeed, the problem may not be in that "others" do not understand "us" but that different knowledges, ways of seeing uncertainty, place, time and scale are not put into conversation on equal grounds. Collective debates on transformation need to be based on the dialogue between different truth regimes seen as equally worthwhile (Behn and Bakker, 2019). Ontological plurality goes beyond adding different types of knowledges together or integrating them. It means asking critical questions about the framing of socio-environmental problems (Nightingale et al., 2020). Of particular concern for us in this paper is how we, researchers in political ecology and rural development contribute to making certain knowledges authoritative. Engaging with the fact that we also co-produce the issues we study (e.g., climate change but also the politics of uncertainty) "makes framings more accountable, transparent and open to scrutiny from other ways of knowing" (Nightingale et al., 2020, 346).

\section{Crisis of Hegemonic Knowledge Production in Political Ecology and Rural Development} There is a long tradition and substantial literature within the social sciences, especially after the cultural and postcolonial turn and the feminist critique of epistemology, arguing for a decolonized and reflexive approach to knowledge production.
Our article is inspired by seminal work on ethnographic authority in anthropology (Clifford, 1983; Clifford and Marcus, 1986; Britzman, 1995; Lassiter, 2005; Gold et al., 2014) and especially the need to question the "unreciprocal quality" (Clifford, 1983) of research encounters. In addition, we find inspiration in ethnographers' attempts to address some of the limitations of fieldwork, among them the colonial representation of the "Other" and the overwhelmingly Western-centric basis of ethnographic authority. We agree with them that research is a performance that is inscribed in power plays, and that it is important to highlight in particular those questions emerging in research processes that most researchers usually do not or cannot hear (Shah, 1999; Pillow, 2003; Manning, 2016). This is because omissions and silences can affect and afflict the process of research (Shah, 1999; Scheper-Hughes, 2000; O'Reilly, 2008) and its real-world consequences.

Mbembe (2001) points out that while social theory makes universal claims, it is built on defining itself in terms of modernity and rationalism, two things also often defined as uniquely Western. Social theory is based on "enlightened" European theories and worldviews, defined as opposed to the "necessarily inferior peoples" of other parts of the world. Is it possible to use such theories to understand those "inferior" peoples? Mbembe asks. The Enlightenment also shattered the bonds of ancient beliefs, differentiating between public and private lives and privileging academic reason and free will. Challenging this heritage in our academic institutions, demands us to incessantly identify and make visible any signs of that which is less rational and more chaotic and affective in our academic work.

Before us, researchers in feminist political ecology and critical development studies have already greatly benefited from insights and approaches described above (e.g., Elmhirst, 2011; Mollett and Faria, 2013; Nightingale, 2013). Yet, despite the fact that these fields build on a critique of how a western-centric bias and colonial gaze has dominated knowledge production, we constantly experience instances where the manifestations of hegemonic and colonial knowledge politics within our fields remain present. As our vignettes indicate, there is a seeming lack of connection between the theoretical acknowledgement of the need to move away from unreciprocal research encounters and hegemonic knowledge politics, and how research is performed on practice. In that sense, research processes that claim to be based on knowledge co-production may find difficult to work creatively with historically inherited unequal power relations that normalize the vulnerabilities of for example indigenous peoples or women (Wijsman and Feagan, 2019, 72).

Simultaneously, the emotional challenges, contradictions or tensions we experience in carrying out our research in ways that align with our ideals of emancipation rarely end up discussed in publications. An important reason for this is, precisely as Mbembe (2001) emphasizes, that academia builds on an Enlightenment rationale that separates reason from emotion. As a result, uncomfortable problems, unexpected and uncertain affect and emotions, are hidden and not publicly discussed. This is what we mean by a continuing crisis of hegemonic knowledge production. 
However, this moment of the pandemic constitutes an opening for emancipation as an affective process, or at least for radically interrogating the socio-environmental processes that contribute to creating and maintaining our world order (Leach et al., 2021). Taking this opportunity, we paused to rethink our ways of accompanying differently situated and unequally affected others in common struggles (Singh, 2017; Velicu and GarcíaLópez, 2018). This article constitutes our response to the call made by academics in the context of the Covid-19 pandemic to deconstruct academia and reconstruct a different, more just one (Corbera et al., 2020; Motala and Menon, 2020; Van Hecken et al., 2020).

Our intention is to contribute to re-thinking knowledge politics by discussing the process of making knowledge. We focus on research encounters, which we understand broadly but in a problematized, manner as "always emotion-laden and imbued with power, reproducing and legitimating social hierarchy" (Militz et al., 2020, 429 italics in original). We understand research encounters as those encounters with persons who we call colleagues, other researchers, research participants, research allies and activists, and any other actors and institutions outside or inside this "research industry" that allow us to produce knowledge (Roy and Uekusa, 2020). We acknowledge that all encounters are with people differently situated in terms of hierarchy, discipline, interests, funding, histories, intersectional differences, emotions, embodiment, and experiences.

\section{AFFECTUAL METHODOLOGY TO UNMASK AND EMBRACE THE WORKINGS OF POWER IN RESEARCH ENCOUNTERS}

To navigate methodologically and collectively the fact that "research-encounters are always emotion-laden and imbued with power, reproducing and legitimating social hierarchy" (Militz, et al., 2020, 429), we use Militz, Faria and Schurr's affectual methodology. Affectual methodology is defined by Sara Ahmed as "how we come into contact with objects and others" [Ahmed, 2014, in Militz et al. (2020), 429]. Affectual methodology situates the researchers and the research participants within research encounters in ways that call for transparency and positionality in particular to lay bare the researchers' privileges. Just like Militz, Faria and Schurr's endeavour, our process of writing this paper was aimed at becoming a collective affectual writing process that would not be about writing "about affect, but through and with affect” (Militz et al., 2020, 430).

Affect and emotions have come to prominence in the wake of feminist and more-than representational theorizing in geography and political ecology (Schipper and Pelling, 2006; Thrift, 2008; Pile, 2010; Seyfert, 2012; Singh, 2013; Müller, 2015; Singh, 2017; Dawney, 2018; González-Hidalgo and Zografos, 2019). Affect is what makes the socio-material hold together or fall apart (Müller, 2015). Emotions such as love, hate, anxiety, fear, irritation or in general affective relations that for example create discrimination (Talaska et al., 2008) are crucial ingredients of politics (Lorimer, 2008; Müller, 2015).
The insufficient engagement with affect and emotions in research on socio-environmental crises has diverted attention from how affect, emotions and socionatural emancipations are interrelated (notable exceptions are Nightingale, 2011; Sultana, 2011; Nightingale, 2013; Sultana, 2015; González-Hidalgo and Zografos, 2017; López et al., 2017; Singh, 2017; Velicu and GarcíaLópez, 2018; González-Hidalgo and Zografos, 2019; Graybill, 2019; González-Hidalgo, 2020). One important consequence has been that "detachment, objectivity, and rationality have been valued, and implicitly masculinized, while engagement, subjectivity, passion and desire have been devalued and frequently feminized" (Anderson and Smith, 2001, 7).

The publications mentioned among the exceptions have essentially focused on environmental change and conflicts rather than reflecting on the very process of researching these. For example, they have shown how processes of environmental change and conflict are not only "economic, social or rational choice issues, but also emotive realities that have a direct bearing on how resources are accessed, used, and fought over" (Sultana, 2011, 163). The perseverance of feminist scholars, together with decolonial and activist scholars among others, has thus facilitated a recent "emotional turn" in political ecology research. However, this turn cannot be completed if the political ecology scholarship in particular, and the academy in general does not systematically use affect and emotions to reflect on and transform its own knowledge generation practices. If the acknowledgement of the ambivalent role of emotions and the aleatory character of affect can let us better understand and engage with grassroots movements engaged into action (González-Hidalgo, 2020), our claim is that we can also bring those experiential, emotional and affective ways of knowing into our everyday practices as researchers and academics.

A reflexive process for discussing the workings of power in research encounters and knowledge-making practices is key in the practice of feminist political ecology (Harcourt et al., 2015). By discussing our positions of privilege as researchers (England, 1994), how our research foregrounds some interpretations and silences others (Jackson, 2006), and how research is embedded in imperialist and colonialist projects (Smith, 1999), we are starting to challenge the practices that reproduce the status quo in academia. Reflexivity is usually an individual practice in which researchers discuss their research interactions and the power relations in which they are embedded. In this collective exercise, we want instead to reflect and learn, not only as individual researchers, but also as inter-related researchers, as a collective. Through dialogue and reflection, we open up a democratic and emancipatory process and want to break with a culture of silence (Freire, 1996). This is because we need to become a critical mass that is self-reflexive about how its practices may be oppressive, and how we may strive to go beyond egoistic academic experience.

Like Militz et al. (2020), we engage with two methods: autoethnography and resonances. Auto-ethnography is intended to "make the emotions and positions constituting research encounters and knowledge production more explicit" (Militz et al., 2020, 430) and to help unravel the workings of power in research processes. However, as Foley (2002) puts it, 
incorporating the researcher's personal self and utilizing a more affective way of knowing is not without problems: autoethnography has been criticized for being a self-indulgent, narcissistic or excessively subjective and shallow process. And, nevertheless, critical autoethnography has the potential to force us to position ourselves, question our responsibilities and reconsider our power to affect others. Militz et al. (2020) also report some of these limitations, explaining how autoethnography can challenge the reader's assumption, without necessarily challenging the researcher's biases. To try and overcome these limitations, just like Militz, Faria, and Schurr did, in this article we engaged in a collective affectual writing process-via resonances-, to make us individually and collectively problematize what we tend to take for granted, the reasons of feeling uncomfortable in certain situations, and how we sometimes tend to "normalize" discomfort, thereby reinforcing unequal power relations.

Our second method, resonances, implied engaging with the emotions triggered by the reading of others' auto-ethnographies during the Covid-19 pandemic. The ways in which we related to our colleagues' emotions during research encounters, and discussing our own emotional and experiential knowledges of research, helped us unmask the privileging involvement of our bodily histories in research encounters (Militz et al., 2020). We are convinced that feelings of connection, disconnection, anger, frustration, irritation, and helplessness (Lee, 2019) expressed in relation to our colleagues' account on their research encounters during the Covid-19 pandemic contribute to revealing what normally tends to be silenced. Our resonances allow us "to share experiences of vulnerability that, potentially, illustrate research encounters in a much more nuanced, multi-layered way" (Militz et al., 2020, 434). This exercise, we argue, can help us to re-think our knowledge production practices seriously.

Concretely, we use vignettes to "write affectually" (Militz et al., 2020, 429), to immerse the reader momentarily in our research. To write up the vignettes, we asked ourselves: what, in some specific research encounters of ours, makes us feel uncomfortable with the ways in which we have engaged with (i.e., acknowledged, worked with, problematized) interconnected vulnerabilities (our own vulnerabilities, that of our colleagues' and our research participants')? This question assumed that we all feel or have felt discomfort, and that we have gut feelings about our own problematic, unequal, unjust engagements that may reinforce (but also help us to challenge) our interconnected vulnerabilities.

Each of the ten co-authors wrote up a vignette that was reflected on by the other co-authors individually in writing. Afterward we discussed each vignette in small groups of three or four and reflected on how we shared and connected similarly or differently with these discomforts and vulnerabilities. In this article, we share three of these vignettes that for us reflect affective and emotional relations through interconnectedness, uncertainty and critical aspects of hegemonic knowledge production. We analyzed these vignettes and the resonances using a broad threefold lens of interconnectedness, uncertainty and critical aspects of knowledge production. In addition, we reflected on the collective process of writing this article as a proxy for how we engage in and access research, how we treat each other, yield authority and legitimacy, even in research encounters with our most direct colleagues. We presented our preliminary findings to other colleagues in our department and in our analysis presented here we also draw on their reactions to the vignettes and to our call for this broader self-reflexive emancipatory process.

We envisioned the process of writing this piece together as empathetic, supportive and friendly. We agreed to strive for appreciating all forms of input to the conversation (be it empirical, theoretical, just a little bit or more), being more attentive to the process than the result. We wanted to discuss and experience how we can become better researchers in our connectedness with differently situated others. While we were committed to be self-critical about our own research practices, ambivalences, and contradictions, in order to build a safe environment among us, we made clear that it was not our intention to criticize ourselves or each other. While this was important for building a safe environment among us, the process was not without some tensions and the fruitful consequences of this process in our future work and work environment are yet to be seen. Perhaps, we hope, we have unleashed an affective and emotional anti-hierarchical pandemic in academia.

In the following section, we present three vignettes about the affective and emotional experiences of being a researcher during the Covid-19 pandemic with some of the resonances of the coauthors. While the vignettes are rich in sharing different contradictory emotions, we have labeled them outlining three main emotional expressions: "Shame and Powerlessness," "The Racialized Burden of Care" and "Uncomfortable Privilege." We have anonymized all the names in the vignettes and resonances. All the names have been changed to unisex names. As pronoun, we use "she" invariably of the actual gender identification of the person.

\section{AUTOETHNOGRAPHY AND RESONANCES}

\section{Shame and Powerlessness}

Leo, a PhD student who conducted field work on mining and state-led extractivism in Northern Sweden in March 2020 during the onset of the Covid-19 pandemic, shares some ethical dilemmas during the process of doing field research, which have been amplified by the pandemic.

(Leo): I sit in my expensive rental car looking up at the house on the hill. I'm bracing myself once again for the strange practice that I have found works best for finding interviewees on my study of mining conflicts in the Swedish north, in the homeland of the indigenous Sami ${ }^{1}$ people. In order to engage with people in the valley where a mining company seeks to open a gigantic nickel mine, I have to barge into people's homes - just opening the door, calling out "Hello! Is anyone home?". They won't open for strangers who knock (it might be peddlers of religion or mines), they rarely answer the phone if you call in advance and if they do, they say that

\footnotetext{
${ }^{1}$ The Sami people are an indigenous Finno-Ugric people inhabiting Sápmi, which today encompasses large northern parts of Norway, Sweden, Finland and the Kola Peninsula within the Murmansk Oblast of Russia. 
they don't have anything to add to my research, that the mining project is a looming threat but one that is too technical for them to address. (Nicky): I would also feel strange about doing this, but only because we are in Sweden, in the Global North. This way of finding interviewees is completely the standard way in the countries where I have been working in the Global South, when it comes to interviewing ordinary people - even with officials, when you try to plan a meeting they sometimes say they don't have time, but showing up at the office often works better. (Elya): I had a similar reaction to Nicky's: while doing research in Nicaragua I used to go directly to people's houses to interview them. But somehow in Hungary, I feel more uncomfortable about doing that. I sense that this discomfort relates to differences in how time is apprehended differently in these places. Thinking about it now, I may have a presumption that in Nicaragua farmers "always have time" while in Hungary "they are busier."

(Leo): We sit and talk, sometimes for the whole afternoon, about the mines, about the history of a valley marred by a century of violations of the Swedish state. We talk about hunting, of wood craft, of living in this remote place and about the conflict between two Sami groups, about incursions and injustices that have made life unbearable for some and they have turned to the bottle or even ended their own lives. I'm horrified and ashamed and powerless. What can I add to this? What will my work accomplish? Am I just another researcher who siphons their experiences for my own gain? As our conversation inevitably turns toward the subject of the Corona pandemic, I hear how they feel that it is creeping up from the south, about to become another threat that will make the withdrawal of the welfare state even more obvious. There are no hospitals and the small health center in town will not be able to cope if there is a larger outbreak. There is talk about what will happen to the tourism if the southerners and the Norwegians don't show up, and talk about what will happen if they do. Pandemic or loss of livelihoods? And I have become the plague bearer. They don't see it that way, not yet. I'm still welcomed but I feel that I'm becoming another threat, meeting and talking to people and walking from house to house. Many of my research participants are elderly, some are already ill in other diseases, and I don't know if I'm infected. The chances are small, but there is also a chance that I bring death with me as I walk into someone's house and have a chat about everyday life over a cup of coffee. (Nicky): The "barging in" without knocking thing is what I find most unusual and strange, and that they would not open if you do knock! I reflect that your description makes it sound so brutal, like a violation, while I imagine they think of it as simply a guest coming to visit. (Elya): I feel it is very brutal, especially in these times of pandemic when you don't know whether you may contaminate people. I may be a bit dramatic but it made me think about the colonization of the Americas by the Spanish and Portuguese when so many indigenous people died due to the fact that the colonizers brought diseases such as chicken pox with them.

(Leo): My need to understand becomes unethical and yet I persist, fearing that I might not get enough information, not enough data. And then I stop and cut my fieldwork short, I need to get home to my family and I can no longer justify my visits. As I drive south, I cannot shake the gnawing feeling that I might have hurt people and nothing else will come out of it. (Nicky): I could really relate to that. How in research you sometimes feel that you shouldn't be insisting on getting more data but you have the pressure of publishing, the pressure of your supervisor, the pressure to produce data ... It is a classical ethical dilemma, the fear of somehow hurting people with your interview, and yet with a Covid twist that it makes it so much more pressing. Earlier you might have visited while experiencing mild flu symptoms and an elderly interviewee might have caught something and even died without us really condemning that behaviour in society. Now it has become highly condemnable and I feel when I read like "no! you have to stop!". (Elya): Yes, the ethical dilemma is not just so much more pressing now with the pandemic but it has also become embodied (Alva): I think giving voice is a responsibility we have when we interview and have achieved the trust of people. Then with all pressures, I still bear with me many stories I have not been able to reflect upon, due to new tasks and academic commitments. Then it feels even more in vain. The researcher's guilt continues when we later on, are unable to return and give back. How can we give back even to those who we share sympathies with? So if we come back we might add to the poison? Make conflicts worse for those we share sympathies for? What are our arenas? And how can we pursue the cause we feel is "righteous"? What are our instruments? Where can we make a difference? Can we make a difference?

Leo's vignette exposes the unpleasant emotions of shame and the ambivalence related to barging in the private homes of people in Northern Sweden. Leo humbly recognizes two sides of a coin: on the one hand, powerlessness to help interviewees directly to whom one feels deeply connected, and on the other hand, being in power and even being a threat, possibly a deadly one, to already vulnerable people. This type of self-reflection working with vulnerable communities, highlighting affective relations, complicates the power and legitimacy of the researcher. This issue is not new for us: several of us have wondered about how we may affect the lives of our research participants when we, due to ideas about what is possible and where the limit for our engagement should go, might refuse to help them when they face difficulties that we view would fall beyond our research related engagement. Even worse, we may burden them with our presence during times of hunger, conflicts or the danger of carrying infectious diseases.

The reflections of other participating researchers on the vignette were mostly related to the dilemma of giving voice in researcher driven inquiries which expose feelings of coming short and inadequate. Often it is the researcher's agenda that is creating the frames of concerns that are to be addressed. Despite our effort to give voice to the concerns of our interviewees, the potential "use-value" of our research is seldom able to remedy the direct concerns of the people who gave their personal time and dedication to our work. This highlights why emotional and affective relations underlying knowledge production practices need more focus: they have the ability to uncover those hegemonic frames that silence the experiential knowledges and alternative knowledge claims.

Moreover, the pandemic exposes extreme inequalities, new, and not yet reflected upon potential burdens inflicted upon 
research participants, making the injustices embedded in research processes more apparent since the sole presence of the researcher could and may have literally killed interviewees. These ethical concerns and the consequences we should take regarding fieldwork when researchers may spread the coronavirus were heatedly discussed in our group. Some of us felt that Leo's testimony should be problematized by involving the $\mathrm{PhD}$ supervisors so that clearer rules on ethical fieldwork practices for the future are put in place. Nevertheless, all of us co-authors working across the Global South and North had experienced similar emotional dilemmas during fieldwork before. Some others felt that if we if we confronted Leo's supervisors about the risk he put his research participants in, the danger would be closing down opportunities to openly discuss our emotional and ethical concerns in the future if these may get reported. Our discussion uncovered not only the kind of colonial legacies shaping most of our research practices, it also showed how strong is the instinct of finding solutions through institutional and regulatory fixes, rather than fully embracing affect and emotions to help us think beyond current hegemonic academic practices. We as political ecologists are yet to establish decolonial research agendas and decolonize our own mindsets, first and foremost.

\section{The Racialised Burden of Care}

Charly is a female professor of African origin living and working in Sweden since 1988. While it is not part of her official duties, she most often takes the "guilt trip" responsibility (as she calls it) for African students far away from their families. This is not different in pandemic times: she supervises many of them and undertakes the responsibility to find them a place to live. She takes them out and shows them around. During the pandemic, she has been more than ever trying to take care of their emotional well-being while also struggling with own problems, as everybody.

(Charly): April 2020: "Everyone in Sweden has a responsibility to prevent the spread," the Public Health Agency's general director Johan Carlson said in a statement announcing the new guidelines ${ }^{2}$ (thelocal.se). The blue link meant I could click on it and get to the guidelines and I did exactly that. I was directly taken to the Swedish website of Folkhälsomyndigheten (the Public Health Agency). I searched for the English icon, clicked on it, and came to the welcome page of the Public Health Agency. What a lot of information - then I wondered how many of my foreign students even knew about the existence of this website. For a while, much of the information about Covid-19 was purely in Swedish, written for people that could speak Swedish, could navigate and find information on the internet in Swedish. They were a forgotten group in terms of general Covid-19 communication. I had at that time three foreign students visiting our university. Sandwich students - that come, stay three to six months, and then go back to their respective countries. I had to inform them of the risks, and that perhaps they should return home to their country. What if something

\footnotetext{
${ }^{2}$ https://www.folkhalsomyndigheten.se/contentassets/ 5733d0f5cba44d9e9069a272f7e98470/hslf-fs-allmanna-rad-om-allas-ansvarCovid-91.pdf Last access 18 December 2020.
}

serious were to happen - did I even understand the formal protocol of how to manage this situation? The weight of the responsibility for the lives of these three students lay upon my shoulders like a cloak of thick mist. To assuage their anxiety, I called them for a WhatsApp audio meeting firstly to let them know I was there for them. Secondly, to ask them that all-important question: would they like to return home to be with their loved ones. They told me that they would confer and get back to me with an answer. The response was one of unity and determination to continue with their studies. The quest for higher education at a price, for a price, and enormous sacrifice. I was unable to shake the thought of one of them getting terribly sick in a land far away from their home. The next WhatsApp session we discussed their fears of being away from their loved ones, the familiar and the loneliness. Interestingly the singular most important thing that they found daunting was if one was to die who would know how to send them off in a way that was befitting of their culture. As one of them emphasized "my mother asked if there are other Africans that can cry for me should I die here." Even in death, we think of that what binds us together culturally and with Covid-19 and for foreign students, this is no different.

(Thando): I have experienced over the years how you Charly have taken on a lot of responsibility for all our African students. All that you have done for these students commonly "fall between chairs" in the Swedish formal system of responsibility and some take this as an excuse not to help out. This resonates with several feelings in me- I get frustrated with that our university provides limited help with all the things around the actual studies, but also I get sad that we as native Swedes are so used to that "the system" takes care of everything in our social life- that there are support networks in the form of a well-established social security system etc. that makes us think that we only need to, and only are morally obliged to, take care of ourselves and to do what is stated in our work-descriptions. This support structure, which in many ways is a good thing, has also led to this individualized behavior which I find distressing. (Alva): My experience from having been a $\mathrm{PhD}$ student from overseas in Canada was that the university had an International Office that had a multifaceted engagement with us including practical and social matters. I feel both personally inadequate for not having been more personally engaged, but also feel that our university should show more engagement for overseas students. The burden should be on the institution. (Nicky): I agree with Thando's comment above, but also, I see that even if there would be better structures at our university, they would still turn to you and you would still feel more obliged than most others, Charly, because of this thing about being an "other African.” (Sam): It reminded me of when I first arrived in Sweden as a $\mathrm{PhD}$ student, and how I knew nothing about the system. Friends and colleagues from my corridor back in Gothenburg were the ones helping me to get "into the system." One of them even offered to host me for a few months if I could not find a place to say. That person became my best friend today! My experience, from the other side of the coin, is that I do not expect the system to help me, as it hardly ever did back in my own country (Thailand). Instead, I rely on my own informal networks and who I know, or who I get to know. I totally understand Charly's frustration and appreciate Charly's generosity of being that 
person who provides support. Charly's story reminds me that I should help more. (Leo): Reading this I get angry and frustrated. First it reminds me of how we at our university, a self-proclaimed bilingual university, continuously fail to provide information in both English and Swedish. For better or worse, English remains the lingua franca in Western academia and yet time and again there are examples where English-speaking colleagues miss out on vital information or get an abbreviated version. Secondly it makes me think of how the administration of Region Västerbotten (a county in the north of Sweden) posted the topic about local recommendations about Covid-19 in Somali on a website that were supposed to be written in Northern Sami. The text in Sami was missing important characters needed to make it understandable. When the Swedish Sami news pointed this out to the Region, they responded with "These things happen, but we think that the message comes across and we don't think the taxpayers should have to pay for the same site twice so we'll keep it this way." That these links do not provide the information needed can be waved away as "Well, it was a human error" point toward how people in Sweden are treated differently during crisis, in this case making indigenous people more vulnerable to a pandemic that is harvesting lives all over the globe. It is an example of colonial practices that have shaped relations between the Sami peoples and the Swedish state for centuries and continue to do so to this day.

Charly's vignette expresses a deep sense of responsibility, and the burdening feelings of worry and sadness for foreign students' isolated situation in Sweden during the Covid-19 pandemic. Several scholars have identified the burden of invisible work in academia contributing to further social inequalities with repercussions on time use, the minority tax, especially by minorities that are largely women (Menges and Exum, 1983; Social Sciences Feminist Network Research Interest Group, 2017). The "cultural tax" (Padilla, 1994) or the "identity tax" (Hirshfield and Joseph, 2012) places enormous expectations and responsibility on certain minority people. According to Padilla, cultural tax is defined and understood as:

The obligation to show good citizenship toward the [academic] institution by serving its needs for ethnic representation on committees, or to demonstrate knowledge and commitment to a cultural group, which may even bring accolades to the institution but which is not usually rewarded by the institution on whose behalf the service was performed $(1994,26)$.

While Charly's colleagues may express their thanks and gratitude to Charly's strong commitment and the cultural bonds she has with the students, they can never fully experience or comprehend the physical, emotional and mental responsibility that Charly bears on behalf of the academic institution (Hirshfield and Joseph, 2012). Indeed, students can open up about their greatest fears and need to be guided through extreme and uncertain situation while institutions such as the university or the state fail to provide timely support to those who do not understand neither Swedish nor the nuances of the Swedish culture. (Hirshfield and Joseph, 2012) refer to this as physically shouldering duties that other staff members may not have and that affects academic production and social integration within the academic department or institution. While Charly, also coming from Sub-Saharan Africa, helps to build trust with the students, there is little academic or institutional reward in providing these services - the invisible work of academia (Social Sciences Feminist Network Research Interest Group, 2017; Jimenez et al., 2019). Her skills and abilities are often referred to "soft skills" or "feminine" unlike those required in research and administration that are referred to as "hard skills" or "masculine" and that are evaluated differently in the reward system. This "care of burden" relies precisely on the affective relations based on a feeling of interconnectedness between foreign people in a foreign country. While they are important and need to be valued (without Charly's extra care and responsibility, many foreign students would suffer more or even not finish their PhD), the Covid-19 pandemic has enabled us as a collegium to highlight this issue in a way that may not have been possible before the pandemic.

The resonances with this vignette reflect anger about the invisible work and minority tax that minority staff shoulder and labor unlike their non-minority counterparts. Exclusionary institutional practices which lead to mental, physical and emotional burden are seldom addressed or applied in assessments of minorities. Similarly, isolation and uncertainty of individuals that need more active nurturing to engage is totally missing as are the resources to work with these issues on a long-term basis. At the same time, several of the coauthors recognize that it is our responsibility as researchers to care for our foreign colleagues and students, without expecting that the system will work. While this demonstrates that the practice of reflections through vignettes helps to raise awareness and the will to help among researchers, it also shows how a deeper engagement with this racialized and naturalized burden is needed: while many Swedish colleagues think that "the system" will take care of students, Charly's work becomes hidden, or seen as "natural" as she is African herself, or a "nice add-on." Being the host institution for overseas research on the Global South implies a commitment by all researchers that the research conducted is not only of importance for our academic environment but that it also builds ethical collaborations. This assumes stepping outside what we perceive as acting according to the "normal" state of affairs, i.e., the needs of "normative" citizens and the assumption that the "good state" has taken care of legitimate needs. The reflections by colleagues remind us of the ethical boundary-making dilemmas of researchers indicated earlier. Our commitment as researchers does not end where the boundaries of our own research concerns end. We have a collective responsibility in our research encounters that we need to fully take up. We need to reward the burden of invisible work, the identity tax in academia and inculcate minority tax in the goals of our academic institutions.

\section{Uncomfortable Privilege}

Lin is a researcher from Germany who has spent long periods in Nepal. Being back in Europe just when the pandemic began, Lin shares how the pandemic is exposing her to unpleasant paradoxes of research from a distance.

(Lin): Being absent, physically, cognitively and emotionally from what I define my "field." My colleagues and research 
assistants in Nepal, who juggle with internet connectivity, working from family homes, and even face harassment in the Covid-19 lockdown world in Kathmandu. My respondents in the villages, whom we can only reach via phone, to whom we have limited, and officially sounding questions, receiving official replies. Information I cannot further probe, as I'm not there during the interview which is conducted through my research assistant. Usually I often adjust questions when I'm in the field, react to whom I meet, what I see. When I don't have this exposure, my mind and work focus wander off to conferences, publications, twitter, my own promotion. After leaving Nepal I became a European academic, who only sometimes is exposed to collect data to write about. Who only sometimes is touched. While these loads of local NGO and national documents which I brought from Nepal are piling up, and my transcribed interview data and field notes are waiting to be analyzed, I prioritize preparing yet another presentation to my Europeanbased academic colleagues. I try to think hard about how to present the data to form an argument to the academic community, but less about the very rich details, the immense reading I should be doing to know better. This may lead me into superficial directions, like of those academics I despised, losing the richness and diverse meanings while trying to form an academic argument. Working remotely during Covid-19 makes me uncomfortable as I realize my distance to other ways of perceiving the world, other meaning making, not being able to be in the field more regularly to organize workshops, expose myself to village life, come closer to the research subjects, to uncover layer, by layer, by layer of social relations, of everyday practices, of change over time, by seasons, by years, and still being far from close to lived realities, but being closer than now. Covid-19 reflects my own privilege and comfort, to think in larger time spans, beyond the next day, the next season, having trust in having job security for years.

(Thando): Like you, I have my field work sites far away from home, across the globe. And I have not been able to go there now during Covid. While Covid has led to a temporary halt on travels your thoughts relate to something larger for me that I have thought about for many years. How do we justify doing research far away in countries where there are researchers, who if they could get the funding we get, could do the research instead? When we publish our research in academic journals, what difference does it make? Should we not instead spend our time trying to lobby for change? Talk to policy makers and write accessible texts and share with those in power? We are flying across the globe, contributing to climate change, and what do we contribute? I justify it to myself with that I as an outsider can see things that you cannot see when you study a society close to your own, and that I, because I am not part of that society, can be more direct in my critique of injustices, than if I relied on that same society for my living. But is this really a relevant and true reflection? To really make this contribution should I not spend more time trying to create change, than trying to publish in high-ranking journals? (Alva): The dilemma of knowing from inside is also part of being in our academic "bubble," which prompts the importance of moving closer, exposing ourselves. Meanwhile, one is bound up with requirements in one's "bubble" inhibiting one from giving feedback and engaging. (Elya): I feel a deep discomfort about this argument that as an outsider you can see better or more things than as an insider. Don't you think that this assumption relates to this argument on the need of being objective and detached? And if so, are we not better see-ers and knowers when we are more connected emotionally, when we are more affected in our hearts, when we feel our research participants' problems because they are also our own ones? (Nicky): I don't think this is an either-or situation, insider research has some clear advantages and outsider research has others. I struggle with the same guilt as Thando on why I am doing this from Sweden. I try to involve local collaborators and share the money I get but also that can be difficult. In South Africa most of the prominent people in my field still seem to be white, which is really frustrating, at the same time as I feel bad for even considering skin color when I choose who to work with, I don't want to think in those terms at all.

Lin's vignette exposes our everyday contradictions of being researchers based in Sweden- with our material privileges such as generous salaries, excellent working conditions and access to health care, - while doing research in other parts of the world, with the collaboration of locals who not only have no access to such good living conditions, but are frequently exposed to acute conflict, economic poverty and hunger. Additionally, it is us, academics in the Global North, who get most credit for the research. The vignette and resonances not only highlight these recognized but usually seldom debated privileges, but also the unpleasant feelings associated with our limited power as researchers to radically transform local and global inequalities as well as the coloniality of knowledge. While some of us feel complicit of reproducing this coloniality, we admit that we do not do much to change it. In particular, the resonances also present how we, as academics, build on self-justifications - such as the possible benefits or absolute limitations of being an outsider- to be able to cope with or silence those unpleasant feelings. The resonances therefore invite us to discuss how these contradictory emotions can be collectively embraced to envision emancipation despite our everyday obligations and our need to have a job in the academic industry.

\section{DISCUSSION: AFFECTIVE EMANCIPATION CHALLENGES THE STATUS QUO IN ACADEMIA}

So, how does the previously described self-reflexive process carried out by ten researchers in the midst of a pandemic help opening up for emancipation?

In what follows, we argue that being critically aware of the importance of affect and emotions in our research processes, being able to recognize them and give space to them is one important step for engaging in emancipatory processes that embrace interconnectedness, uncertainty and challenge hegemonic knowledge production practices.

\section{Relational Vulnerability: Research Encounters as Affective Space}

We argue that our analytical focus on interconnectedness helps to better engage with the relational character of vulnerability 
(Taylor, 2013; Tschakert and Tuana, 2013). Vulnerability has been a central topic for political ecologists (Forsyth, 2008; Fazey et al., 2010; Cuomo, 2011; Tschakert et al., 2013; Djoudi et al., 2016; Nagoda and Nightingale, 2017; Nightingale, 2017; Velicu and García-López, 2018; Arifeen and Eriksen, 2020; Fernando, 2020b). Yet, the relational and interconnected processes through which vulnerabilities are produced and challenged (and sometimes both at the same time) via research encounters have been much less discussed in political ecology scholarship. We argue that engaging with vulnerability in a relational way, as the ability to affect and to be affected, can help (more) meaningful and just research collaborations. For example, Leo, in her process of doing interviews in Northern Sweden during the pandemic feels that she can potentially "bring death" to the people who she visits (and also risks getting contaminated by the virus). This shared sense of vulnerability makes her (and us through our resonances) question our responsibilities as researchers: research encounters do not only solely produce "data." We also produce vulnerabilities at the same time in which we become more vulnerable. Yet, hegemonic knowledge politics that do not give enough space to discuss the relational making of these vulnerabilities contributes to reinforcing the status quo in academia. An academia that is still far from properly deconstructing and understanding its own problematic history as a Eurocentric construction and the implications of this (Mbembe, 2001).

To open up the ways for emancipation, extraction of data and imposition of knowledge claims must be replaced by affective connections and relational becoming through shared vulnerabilities. A more coherent theorization of spaces of research encounters as affective spaces is required to recognize that the technologies, social relations, and arenas of participation are interdependent and that the modalities and spaces of power and empowerment are entangled (Kesby, 2007).

When we engage with relational vulnerability within our research collectives, we should not lose sight of the fact that we have differential vulnerabilities that depend on our personal, historical and collective situations as well as our positionality at a given time and in a given place. For example, by opening up for our own vulnerabilities in this process of writing this article, we do not risk losing our jobs. This is not the case for people who, by opening up to emotions may open up for being harmed. One way of mitigating this risk is the focus on relationality: it helps to decenter from individualized emotions and replace them with affective relationships with others. Then, if we take seriously how vulnerability flows in our collective, we can open up for the practice of "slow scholarship" (Caretta and Faria, 2020), so that we and others involved in the research process take the time to reflect, discuss and decide what is needed for our scholarship to become emancipatory.

The question however remains: with their pervasive focus on power and inequality, can political ecologists practice and produce honest "collaborative ethnographies" (Lassiter, 2005; Gold et al., 2014) with their research participants? Our response is that what first needs to be deconstructed are our current practices and assumptions about research collaborations. First, our vignettes show that we all bear the institutional and sometimes self-imposed burden of collaborations. Yet, due to our incapacity and sometimes unwillingness to question the comfortable status quo in which we are embedded as researchers, we continue reproducing unequal power relations and processes that make our research participants vulnerable in and because of these collaborations. If we were to describe and reflect on the process of writing this article as a "collaborative auto-ethnography" between scholars, our analysis would have to discuss how our process may have reproduced some of the same unequal power relations and inequalities that served as the initial motivation for coming together. One manifestation of these unequal power relations that have to some extent marked our collaboration for this article are for example the fact that both the co-authors who are $\mathrm{PhD}$ students were suggested by their supervisors: they did not initially respond to our open call. While this may not imply that they benefitted less from the collaboration, it definitely raises questions about the voluntary character of research collaborations such as this one, especially for junior colleagues. Also, while we had envisioned a caring and supportive collaboration process, there were moments when discussions on the auto-ethnographies created tensions in the group: we have not been able to achieve consensus on all interpretations. For example, comments on auto-ethnographies made with the intention of promoting a decolonial approach, emphasizing indigenous people's quest to define participation in research, were by some understood as being judgmental toward the researcher and enounced from a position of authority. Also, the writing-up process beyond the ethnographies did not end up being as collaborative and mutually supportive as we had initially envisioned it- again with time being a constraining factor.

Second, based on our reflection through the autoethnographies, but also on the process of writing this paper, we see a contradiction emerging between our will to resonate with each other and our desire to contribute to emancipation. Indeed, reflecting back on the process of writing this article, we wonder whether frictions, misunderstandings and (productive) conflicts could have been more conducive to envision pathways for emancipation. As stated by Wijsman and Feagan, "rather than collaboration at all cost, conflicts, contradictions, and friction are the critical points for transformative interventions" (2019, 73-74). This discussion goes beyond the purpose of this paper, nevertheless, we need to bear in mind that there is no recipe to open up for emancipatory pathways.

\section{Embracing Uncertainty and the Unknown in Research Processes can Provoke us to Think Differently}

The very definition of academic inquiry as rational, modern and free from any shackles of subjectivity, unsubstantiated beliefs or affectual understandings is closely connected to the portraying of non-Western societies as inferior, irrational and chaotic. Upholding this academic self-image in fact requires the disguising and hiding of those less rational and objective instances of our own knowledge production that we all know take place. However, we are no longer able to play along with those academic standards that help uphold a colonial and 
problematic image of academia, and this is why we need to insist on revealing, discussing and problematizing the more chaotic, affectual, aleatory, and irrational aspects of academic knowledge production. Only through dismantling and rebuilding our own institution to become more engaging and inclusive can we better understand the multifaceted, complex, uncertain, unknowable and chaotic world. An understanding that values the different ways of making sense of our world is needed in order to break free from our current trap of co-producing oppression, inequality, vulnerability and exploitation.

Affect draws attention to the uncertain dimensions of both research processes and research outcomes. Because of this, our preoccupations should not be about results such as whether Leo will have enough data for her PhD thesis, if Charly's African students will make it through the Swedish $\mathrm{PhD}$ program or if Lin's project will be able to collect field data despite the travel restrictions. Rather, what matters for emancipation is the kind of relations that we as researchers are establishing when we are involved in research processes (interviewing in the Swedish North, mentoring African $\mathrm{PhD}$ students in Sweden, interviewing remotely and through a research assistant in Nepal). How do these relations reinforce unequal power relations, vulnerabilities, the colonial legacies of our academic practices? And how can they become emancipatory?

If we focus on the types of relations we want to build rather than on outcomes, uncertainty should not contribute to paralyzing our actions and to maintaining the inertia in academia. In the case of writing this article, we initially agreed that if we did not manage to publish anything, our endeavor should still help us to feel better in the difficult context in which we are living.

Again, just like embracing interconnectedness, working with uncertainty requires time and slow scholarship (Caretta and Faria, 2020). While it is difficult for us to envision how our academic department could shift to slow scholarship from one day to another, we see the establishment of a small research laboratory as a potentially feasible start. In such a laboratory, a group of researchers could pilot a research and mentoring project based on the building of meaningful and affective relations, fostered though time and care, and geared toward radically transforming research relations.

\section{Space to Discuss Affect and Emotions in Knowledge-Making Practices, and to Challenge Hegemonic Knowledge Politics}

Our vignettes and resonances show how our knowledge generating practices are always mediated by and constituted through affect, emotions and embodied experiences. Our autoethnographic exercise with resonances also revealed how we tend to silence our emotional and vulnerable sides as academics and how we tend to downplay the importance of affective relations underpinning research encounters. While feminists and emotional political ecologists and geographers have acknowledged how these emotions and embodied experiences can "shift (...) notions of essentialisms and question (...) relational privileges, struggles, and differences"
(Sultana, 2021, 4), our emotional engagements in academia still tend to be considered as "secondary," "subjective," and "feminine" or as something to be hidden or discussed in private conversations.

The feelings of discomfort about privileges and disadvantages-which our self-reflexive process has shown to be more common than we individually might have thought it would be - appears to be key in that they potentially represent openings for putting emancipation back on the academic agenda. Racialized privileges and oppressions come particularly to their crystallization point in times of crises as shown through Charly's account. As the only professor of African origin in her department, African students have been long under Charly's responsibility. But the resonances to Charly's testimony shows how her case reflects only the tip of the iceberg. This exercise helped us recognize that our own fields of research, as we practice them, are constrained by what Oswin (2020) calls the "systemic injustice" in her own discipline of geography, which is reproduced globally and institutionally often in imperceptible and naturalized ways. Emotions and affective relations are catalyzers for helping to think about radical changes because they make us feel, deep inside of ourselves, that there is something profoundly wrong and we need to do something about it.

In different accounts and resonances there were expressions of guilt: for not giving back to the research participants (research findings but also not helping people when in need). Also, during our writing process, one of the co-authors expressed how she felt helplessness in the face of the whole exercise we were undertaking while so many people were suffering in physical, economic, and social terms, and we, academics, meanwhile, were spending our time on "another self-centered and egoistic" exercise as she called our endeavor for this article. As a Southern European citizen working as a post-doctoral researcher in a Nordic country, she criticized her own, insufficient abilities for transforming unequal socio-environmental relations from within academia, while at the same time she was paradoxically reinforcing the system by putting efforts in finding a permanent academic position. Or another of us, who expressed in one of our interactions that she felt ashamed that she has been blind for so long to the exclusions faced by her research assistant: "I should have known," she said.

Beyond an individual consideration of those emotions such as guilt, helplessness or "lack of knowledge," we want to stress how the pandemic gives us an opportunity to "know better," "to know differently." To be able to envision emancipatory processes to take place, we suggest research agendas geared toward answering uncomfortable questions such as: how can emotions such as guilt catalyze change in academia? And therefore, on the contrary, How does the fact that we tend to push away those "negative" emotions - or to self-calm them- contribute to reproducing oppressive relations in academia? And more generally: how do we, researchers interested in challenging vulnerabilities, become their very perpetrators?

While it is difficult to pinpoint how our knowledge-generation practices have been transformed after this affective exercise, even when we will be vaccinated against the disease, we may think twice about whether another fieldwork trip of ours is needed to a different country. As Nicky put it: "I feel outraged that people in 
Africa still see no light of any vaccine and it would feel too wrong to turn up in field boasting my healthy, well-nourished body, now also vaccinated against a disease people are still struggling with. And yet, this is not much different to before when I walked around healthy and protected from the many diseases plaguing the people around me, including malaria, yellow fever, hepatitis ..." While, we may have been aware of these injustices before the pandemic, we have now opened a new and hopefully safe space to talk about it. In addition, we discussed to share the reflections underpinning this paper with the rest of our colleagues, write recommendations for our university's policy-makers and a manifesto for researchers to embrace the emotional turn. We also want to push our university department's leadership to engage with investigating the unequal burden of care that is taken by different people at the department, which is so clearly divided along gendered and racialized lines.

The transformation of our knowledge generation practices has just begun with this process and will take several years and unpredictable paths. Yet, we can say that by focusing on affective relations, we have felt how we can gain access to different ways of knowing. Rather than for example trying to understand "only intellectually" how Sami people in Sweden are affected by mining projects as in Leo's research, our exercise has shown that equally important is to understand the reactions of our bodies in, and the human and non-human affects that flow from encounters with Sami people, institutions, technologies and procedures. What are our emotions doing to us and our research practices (Ahmed, 2014)? How can blurring boundaries between researchers and research participants through affective relations help us to better engage in emancipatory socio-environmental struggles?

Also, if we think about research problems in an affective way, solidarity and conditions of empathy and compassion become more central. For example, reflecting on the cultural tax that Charly is bearing in our university department provoked empathy among us: this may be the beginning of a crack in our university system to challenge its practices that naturalize but also fail to value those "soft" research skills that are necessary for making the university function.

\section{CONCLUSION}

To engage with the fact that current research, including our own, struggles to break free from established categories, we need to challenge the politics of knowledge production (Nightingale et al., 2020). Yet, both interconnectedness and uncertainty become less of a concern when plural ways of knowing such as affective, embodied and experiential are held in conversation (hooks, 1989; López et al., 2017; Nightingale et al., 2020; Sultana, 2020). Decolonial, feminist and indigenous scholarship helps question the dominant Western ontology and epistemology that contributes to reducing the multiplicity of knowledges thereby "unauthorizing" subaltern knowledges (Spivak, 1988) because they hardly fit in modern understandings of science, data, scales, and temporality (de Sousa Santos, 2009).
Our paper has only been a first exercise to open up a conversation on how allowing emotions and affect in our knowledge generating practices can make us become better researchers. In order to collectively use these emotions as catalyzers for individual and collective emancipation, as academics we would probably need more safe opportunities for sharing and reflecting on our ambivalent emotions, in ways in which we can discuss their importance in our knowledge production processes. The emotional and affective space is (also) a space of power and of potential conflict that can be harming but also conducive to different, non-hegemonic knowledge politics. The type of affective exercise we have undertaken will not radically change the academic system; however, by opening up a debate, we see the potential of these processes to become the spark that could transform us considerably - as individual researchers, but also as a collective body.

\section{DATA AVAILABILITY STATEMENT}

The original contributions presented in the study are included in the article/Supplementary Material, further inquiries can be directed to the corresponding author.

\section{AUTHOR CONTRIBUTIONS}

1) Conception and design (Original conception and design of project and idea for this paper; Input into discussions at start of project): NG 2) Data collection and analysis (vignettes and resonances): Writing up vignettes: NG, SL, MG, LC, AS, FH, IA, KF, AK, and AA Vignettes selected for paper: SL, LC, and AS Discussing vignettes and resonances: NG, SL, MG, LC, AS, FH, IA, KF, AK, and AA Analyzing vignettes: NG, SL, and MG 3) Writing of paper First drafting of paper (introduction, conceptual and methodological approach, discussion): NG Comments and additions on first draft, strengthening of arguments and additional literature: SL, and MG Round of commenting and complementing the paper: NG, SL, MG, LC, FH, IA, KF, and AK Last revisions and complementing for last draft: SL, FH, KF, and MG Finalization and last revisions, solving some "disagreements": NG Formatting, addressing copy-editing suggestions, submission: NG.

\section{FUNDING}

NG received support from the Swedish Research Council for Sustainable Development (Formas), grant number 2018-00442, as well as from the Swedish Research Council (VR), grant number 2018-05866. SL benefitted from the support of the Swedish Research Council for Sustainable Development (Formas), grant number 2018-00574. The Swedish International Development Agency (Sida) through the Bilateral Capacity Building Programme generously supported LC; University of Rwanda project L1924_6 and University of Dar es Salaam project 2231 
programme. LC also acknowledges support by the Swedish Research Council (VR), grant no 2018-05893. FH and KF are

\section{REFERENCES}

Ahmed, S. (2014). The Cultural Politics of Emotion. Second Edition. Edinburgh: Edinburgh University Press.

Anderson, K., and Smith, S. J. (2001). Editorial: Emotional Geographies. Trans. Inst. Br. Geog. 26 (1), 7-10. doi:10.1111/1475-5661.00002

Anderson, B. (2012). Affect and Biopower: towards a Politics of Life. Trans. Inst. Br. Geogr. 37 (1), 28-43. doi:10.1111/j.1475-5661.2011.00441.x

Arifeen, A., and Eriksen, S. (2020). The Politics of Disaster Vulnerability: Flooding, post-disaster Interventions and Water Governance in Baltistan, Pakistan. Environ. Plann. E: Nat. Space, 3 (4), 1137-1157. doi:10.1177/ 2514848619880899

Behn, C., and Bakker, K. (2019). Rendering Technical, Rendering Sacred: The Politics of Hydroelectric Development on British Columbia's Saaghii Naachii/ Peace River. Glob. Environ. Polit. 19 (3), 98-119. doi:10.1162/glep_a_00518

Blythe, J., Silver, J., Evans, L., Armitage, D., Bennett, N. J., Moore, M. L., et al. (2018). The Dark Side of Transformation: Latent Risks in Contemporary Sustainability Discourse. Antipode 50 (5), 1206-1223. doi:10.1111/anti.12405

Britzman, D. P. (1995). "The Question of Belief": Writing Poststructural Ethnography. Int. J. Qual. Stud. Edu. 8 (3), 229-238. doi:10.1080/ 0951839950080302

Butler, J. (1990). Gender Trouble: Feminism and the Subversion of Identity. New York, London: Routledge.

Butler, J. (1997). The Psychic Life of Power: Theories in Subjection. Stanford, California, USA: Stanford University Press.

Caretta, M. A., and Faria, C. V. (2020). Time and Care in the "Lab" and the "Field": Slow Mentoring and Feminist Research in Geography. Geographical Rev. 110 (1-2), 172-182. doi:10.1111/gere.12369

Clifford, J., and Marcus, G. E. (1986). Writing Culture: The Poetics and Politics of Ethnography: a School of American Research Advanced Seminar. Berkeley, Los Angeles, London: Univ of California Press.

Clifford, J. (1983). On Ethnographic Authority. Representations 2, 118-146. doi: $10.2307 / 2928386$

Corbera, E., Anguelovski, I., Honey-Rosés, J., and Ruiz-Mallén, I. (2020). Academia in the Time of COVID-19: Towards an Ethics of Care. Planning Theory \& Practice, 21 (2),1-9. doi:10.1080/14649357.2020.1757891

Cuomo, C. J. (2011). Climate Change, Vulnerability, and Responsibility. Hypatia 26 (4), 690-714. doi:10.1111/j.1527-2001.2011.01220.x

Dawney, L. (2018). The Affective Life of Power. London, England: SAGE Publications Sage UK.

de Sousa Santos, B. (2009). A Non-occidentalist West? Learned Ignorance and Ecology of Knowledge. Theor. Cult. Soc. 26 (7-8), 103-125. doi:10.1177/ 0263276409348079

Deryugina, T., Shurchkov, O., and E Stearns, J. (2021). Covid-19 Disruptions Disproportionately Affect Female Academics. National Bureau of Economic Research. doi:10.3386/w28360

Djoudi, H., Locatelli, B., Vaast, C., Asher, K., Brockhaus, M., Basnett Sijapati, B., et al. (2016). Beyond Dichotomies: Gender and Intersecting Inequalities in Climate Change Studies. Ambio 45 (3), 248-262. doi:10.1007/s13280-016-0825-2

Dyer, O. (2020). Covid-19: Black People and Other Minorities Are Hardest Hit in US. BMJ 369, m1483. doi:10.1136/bmj.m1483

Elmhirst, R. (2011). Introducing New Feminist Political Ecologies. Geoforum 42 (2), 129-132. doi:10.1016/j.geoforum.2011.01.006

England, K. V. L. (1994). Getting Personal: Reflexivity, Positionality, and Feminist Research*. The Prof. geographer 46 (1), 80-89. doi:10.1111/j.00330124.1994.00080.x

Eriksen, S. H., Nightingale, A. J., and Eakin, H. (2015). Reframing Adaptation: The Political Nature of Climate Change Adaptation. Glob. Environ. Change 35, 523-533. doi:10.1016/j.gloenvcha.2015.09.014

Fazey, I., Kesby, M., Evely, A., Latham, I., Wagatora, D., Hagasua, J.-E., et al. (2010). A Three-Tiered Approach to Participatory Vulnerability Assessment in the Solomon Islands. Glob. Environ. Change 20 (4), 713-728. doi:10.1016/ j.gloenvcha.2010.04.011 acknowledging the support of the Swedish Research Council for Sustainable Development (Formas), grant number 2019-01995.

Feola, G. (2015). Societal Transformation in Response to Global Environmental Change: A Review of Emerging Concepts. Ambio 44 (5), 376-390. doi:10.1007/ s13280-014-0582-z

Ferguson, J. (1990). The Anti-politics Machine:'development', Depoliticization and Bureaucratic Power in Lesotho. Cambridge. CUP stands for Cambridge University Press.

Fernando, J. L. (2020a). From the Virocene to the Lovecene Epoch: Multispecies justice as Critical Praxis for Virocene Disruptions and Vulnerabilities. J. Polit. Ecol. 27 (2020), 685-721. doi:10.2458/v27i1.23816

Fernando, J. L. (2020b). The Virocene Epoch: the Vulnerability Nexus of Viruses, Capitalism and Racism. J. Polit. Ecol. 27 (2020), 635-684. doi:10.2458/ v27i1.23748

Foley, D. E. (2002). Critical Ethnography: The Reflexive Turn. Int. J. Qual. Stud. Edu. 15 (4), 469-490. doi:10.1080/09518390210145534

Forsyth, T. (2008). Political Ecology and the Epistemology of Social justice. Geoforum 39 (2), 756-764. doi:10.1016/j.geoforum.2006.12.005

Freire, P. (1996). Pedagogy of the Oppressed Penguin. London: Penguin Books.

Galindo, M. (2020). Desobedencia, por tu culpa voy a sobrevivir. La Voragine, Available at: https://lavoragine.net/desobediencia-por-tu-culpa-voy-asobrevivir/. (Accessed 26.03.2020).

Gold, A. G., Gujar, B. R., Gujar, M., and Gujar, C. (2014). Shared Knowledges: Family, Fusion, Friction, Fabric. Ethnography 15 (3), 331-354. doi:10.1177/ 1466138114533458

González-Hidalgo, M., and Zografos, C. (2017). How Sovereignty Claims and "negative" Emotions Influence the Process of Subject-Making: Evidence from a Case of Conflict over Tree Plantations from Southern Chile. Geoforum 78, 61-73. doi:10.1016/j.geoforum.2016.11.012

González-Hidalgo, M., and Zografos, C. (2019). Emotions, Power, and Environmental Conflict: Expanding the 'emotional Turn' in Political Ecology. Prog. Hum. Geogr. 44, 235-255. doi:10.1177/0309132518824644

González-Hidalgo, M. (2020). The Ambivalent Political Work of Emotions in the Defence of Territory, Life and the Commons. Environ. Plann. E: Nat. Space 0 (0), 251484862096173. doi:10.1177/2514848620961737

Graybill, J. K. (2019). Emotional Environments of Energy Extraction in Russia. Ann. Am. Assoc. Geogr. 109 (2), 382-394. doi:10.1080/24694452.2018.1537843

Harcourt, W., Ingrid, I. L., and Nelson (2015). Practicing Feminist Political Ecologies. Moving beyond the 'Green Economy'. Chicago, USA: University of Chicago press. doi:10.5040/9781350221970

Herman, E., Nicholas, D., Watkinson, A., Rodríguez-Bravo, B., Abrizah, A., Boukacem-Zeghmouri, C., et al. (2021). The Impact of the Pandemic on Early Career Researchers: what We Already Know from the Internationally Published Literature. Profesional de la Información 30 (2), 1-17.

Hirshfield, L., and Joseph, T. D. (2012). 'We Need A Woman, We Need A Black Woman': gender, race, and identity taxation in the academy, Gender and Education. 24 (2), 213-227. doi:10.1080/09540253.2011.606208

hooks, B. (1989). Choosing the Margin as a Space of Radical Openness. FrameworkThe J. Cinema Media (36), 15-23.

hooks, B. (2003). Teaching Community: A Pedagogy of hope, New York: Routledge. 36.

Jackson, C. (2006). Feminism Spoken Here: Epistemologies for Interdisciplinary Development Research. Dev. Change 37 (3), 525-547. doi:10.1111/j.0012155x.2006.00489.x

Jimenez, M. F., Laverty, T. M., Bombaci, S. P., Wilkins, K., Bennett, D. E., and Pejchar, L. (2019). Underrepresented Faculty Play a Disproportionate Role in Advancing Diversity and Inclusion. Nat. Ecol. Evol. 3 (7), 1030-1033. doi:10.1038/s41559-019-0911-5

Kesby, M. (2007). Spatialising Participatory Approaches: the Contribution of Geography to a Mature Debate. Environ. Plan. A. 39 (12), 2813-2831. doi:10.1068/a38326

Lassiter, L. E. (2005). The Chicago Guide to Collaborative Ethnography. Chicago: University of Chicago Press. doi:10.7208/chicago/9780226467016.001.0001

Leach, M., MacGregor, H., Scoones, I., and Wilkinson, A. (2021). Post-pandemic Transformations: How and Why COVID-19 Requires Us to Rethink Development. World Dev. 138, 105233. doi:10.1016/j.worlddev.2020.105233 
Lee, A. (2019). Hierarchical Microaggressions in Higher Education Settings: Anyone Can Be a Victim, Perpetrator, or Bystander. NCID Currents 1 (1), 20-37. doi:10.3998/currents.17387731.0001.103

Levine, R. L., and Rathmell, W. K. (2020). COVID-19 Impact on Early Career Investigators: a Call for Action. Nat. Rev. Cancer 20 (7), 357-358. doi:10.1038/ s41568-020-0279-5

Li, T. M. (2007). The Will to Improve: Governmentality, Development, and the Practice of Politics. Durham and London: Duke University Press. doi:10.1515/ 9780822389781

López, G., Gustavo, A., Velicu, I., and D’Alisa, G. (2017). Performing Counterhegemonic Common(s) Senses: Rearticulating Democracy, Community and Forests in Puerto Rico. Capitalism Nat. Socialism 28 (3), 88-107. doi:10.1080/ 10455752.2017 .1321026

Lorimer, H. (2008). Cultural Geography: Non-representational Conditions and Concerns. Prog. Hum. Geogr. 32 (4), 551-559. doi:10.1177/0309132507086882

Manning, J. (2016). Constructing a Postcolonial Feminist Ethnography. J. Organizational Ethnography. 5(2):90-105. doi:10.1108/joe-01-2016-0002

Mbembe, A. (2001). On the Postcolony, Berkeley, Los Angeles, London: Univ of California Press. 41.

Mbembe, A. (2020). The Universal Right to Breathe. Available at: https://critinq. wordpress.com/2020/04/13/the-universal-right-to-breathe (Accessed 1304 2020).

Menges, R. J., and Exum, W. H. (1983). Barriers to the Progress of Women and Minority Faculty. J. Higher Edu. 54 (2), 123-144. doi:10.1080/ 00221546.1983.11778167

Menton, M., Milanez, F., Souza, J. M. d. A., Cruz, F. S. M., and Felipe Sotto, M. C. (2021). The COVID-19 Pandemic Intensified Resource Conflicts and Indigenous Resistance in Brazil. World Dev. 138:105222. doi:10.1016/ j.worlddev.2020.105222

Militz, E., Faria, C., and Schurr, C. (2020). Affectual Intensities: Writing with Resonance as Feminist Methodology. Area 52 (2), 429-436. doi:10.1111/ area. 12584

Mollett, S., and Faria, C. (2013). Messing with Gender in Feminist Political Ecology. Geoforum 45, 116-125. doi:10.1016/j.geoforum.2012.10.009

Motala, S., and Menon, K. (2020). In Search of the 'new normal': Reflections on Teaching and Learning during Covid-19 in a South African university. South. Afr. Rev. Edu. 26 (1), 80-99.

Müller, M. (2015). "Assemblages and Actor-Networks: Rethinking Socio-Material Power, Politics and Space". Geogr. Compass 9 (1):27-41. doi:10.1111/ gec3.12192

Nagoda, S., and Nightingale, A. J. (2017). Participation and Power in Climate Change Adaptation Policies: Vulnerability in Food Security Programs in Nepal. World Dev. 100, 85-93. doi:10.1016/j.worlddev.2017.07.022

Nightingale, A. J., Eriksen, S., Taylor, M., Forsyth, T., Pelling, M., Newsham, A., et al. (2020). Beyond Technical Fixes: Climate Solutions and the Great Derangement. Clim. Dev. 12 (4), 343-352. doi:10.1080/17565529.2019.1624495

Nightingale, A. J. (2011). Beyond Design Principles: Subjectivity, Emotion, and the (Ir)Rational Commons. Soc. Nat. Resour. 24 (2), 119-132. doi:10.1080/ 08941920903278160

Nightingale, A. (2013). Fishing for Nature: the Politics of Subjectivity and Emotion in Scottish Inshore Fisheries Management. Environ. Plan. A. 45 (10), 2362-2378. doi:10.1068/a45340

Nightingale, A. J. (2017). Power and Politics in Climate Change Adaptation Efforts: Struggles over Authority and Recognition in the Context of Political Instability. Geoforum 84, 11-20. doi:10.1016/j.geoforum.2017.05.011

Nightingale, A. J. (2019). Commoning for Inclusion? Commons, Exclusion, Property and Socio-Natural Becomings. Int. J. Commons 13 (1), 16-35. doi:10.18352/ijc.927

O'Reilly, K. (2008). Key Concepts in Ethnography. London: Sage.

Oldekop, J. A., Horner, R., Hulme, D., Adhikari, R., Agarwal, B., Alford, M., et al. (2020). COVID-19 and the Case for Global Development. World Dev. 134, 105044. doi:10.1016/j.worlddev.2020.105044

Oswin, N. (2020). An Other Geography. Dialogues Hum. Geogr. 10 (1), 9-18. doi:10.1177/2043820619890433

Padilla, A. M. (1994). Research News and Comment: Ethnic Minority Scholars; Research, and Mentoring: Current and Future Issues. Educ. Res. 23 (4), 24-27. doi:10.3102/0013189x023004024
Paranage, K. (2019). The Mahaweli Development Project and the 'rendering Technical'of Agrarian Development in Sri Lanka. Heliyon 5 (6), e01811. doi:10.1016/j.heliyon.2019.e01811

Patterson, J., Schulz, K., Vervoort, J., van der Hel, S., Widerberg, O., Adler, C., et al. (2017). Exploring the Governance and Politics of Transformations towards Sustainability. Environ. Innov. Societal Transitions 24, 1-16. doi:10.1016/ j.eist.2016.09.001

Pile, S. (2010). Emotions and Affect in Recent Human Geography. Trans. Inst. Br. Geogr. 35 (1), 5-20. doi:10.1111/j.1475-5661.2009.00368.x

Pillow, W. (2003). Confession, Catharsis, or Cure? Rethinking the Uses of Reflexivity as Methodological Power in Qualitative Research. Int. J. Qual. Stud. Educ. 16 (2), 175-196. doi:10.1080/0951839032000060635

Pinho-Gomes, A-C., Peters, S., Thompson, K., Hockham, C., Ripullone, K., Woodward, M., et al. (2020). Where Are the Women? Gender Inequalities in COVID-19 Research Authorship. BMJ Glob. Health 5 (7), e002922. doi:10.1136/bmjgh-2020-002922

Roy, R., and Uekusa, S. (2020). Collaborative Autoethnography: "self-Reflection" as a Timely Alternative Research Approach during the Global Pandemic. Qual. Res. J. 20(4):383-392. doi:10.1108/qri-06-2020-0054

Roy, A. (2020). The Pandemic Is a portal. Financial Times. Available at: https:// www.ft.com/content/10d8f5e8-74eb-11ea-95fe-fcd274e920ca (Accessed April 3, 2020).

Scheper-Hughes, N. (2000). Ire in Ireland. Ethnography 1 (1), 117-140. doi:10.1177/14661380022230660

Schipper, L., and Pelling, M. (2006). Disaster Risk, Climate Change and International Development: Scope for, and Challenges to, Integration. Disasters 30 (1), 19-38. doi:10.1111/j.1467-9523.2006.00304.x

Scoones, I., and Stirling, A. (2020). The Politics of Uncertainty: Challenges of Transformation. London: Taylor \& Francis. doi:10.4324/9781003023845

Scoones, I., Stirling, A., Abrol, D., Atela, J., Charli-Joseph, L., Eakin, H., et al. (2020). Transformations to Sustainability: Combining Structural, Systemic and Enabling Approaches. Curr. Opin. Environ. Sustain., 42, 65, 75. doi:10.1016/ j.cosust.2019.12.004

Scoones, I. (2016). The Politics of Sustainability and Development. Annu. Rev. Environ. Resour. 41, 293-319. doi:10.1146/annurev-environ-110615-090039

Seyfert, R. (2012). Beyond Personal Feelings and Collective Emotions: Toward a Theory of Social Affect. Theor. Cult. Soc. 29 (6), 27-46. doi:10.1177/ 0263276412438591

Shah, A. (1999). Power Plays: Reflections on the Process of Submitting an Undergraduate Dissertation. Area 31 (4), 307-312. doi:10.1111/j.14754762.1999.tb00097.x

Singh, N. M. (2013). The Affective Labor of Growing Forests and the Becoming of Environmental Subjects: Rethinking Environmentality in Odisha, India. Geoforum 47, 189-198. doi:10.1016/j.geoforum.2013.01.010

Singh, N. M. (2017). Becoming a Commoner: The Commons as Sites for Affective Socio-Nature Encounters and Co-becomings. ephemera: Theor. Polit. Organ. 17 (4), 751-776.

Smith, L. T. (1999). Decolonizing Methodologies: Research and Indigenous Peoples. London and New York: Zed Books Ltd.

Social Sciences Feminist Network Research Interest Group (2017). The burden of Invisible Work in Academia: Social Inequalities and Time Use in Five university Departments. Humboldt J. Soc. Relations 39, 228-245. doi:10.1093/sw/18.5.67

Spivak, G. C. (1988). "Can the Subaltern Speak?," in Nelson and GrossbergMarxism and the Interpretation of Culture (London: Macmillan).

Stirling, A. (2015). "Emancipating Transformations: from Controlling the Transition'to Culturing Plural Radical Progress," in The Politics of green Transformations. London: Routledge, 72-85.

Sultana, F. (2011). Suffering for Water, Suffering from Water: Emotional Geographies of Resource Access, Control and Conflict. Geoforum 42 (2), 163-172. doi:10.1016/j.geoforum.2010.12.002

Sultana, F. (2015). "Emotional Political Ecology," in The International Handbook of Political Ecology, 633-645.

Sultana, F. (2021). Political Ecology 1: From Margins to cente Progr. Human Geogr. 45, 156-165. doi:10.1177/0309132520936751

Talaska, C. A., Fiske, S. T., and Chaiken, S. (2008). Legitimating Racial Discrimination: Emotions, Not Beliefs, Best Predict Discrimination in a Meta-Analysis. Soc. Just Res. 21 (3), 263-296. doi:10.1007/s11211-008-0071-2 
Taylor, M. (2013). Climate Change, Relational Vulnerability and Human Security: Rethinking Sustainable Adaptation in Agrarian Environments. Clim. Dev. 5 (4), 318-327. doi:10.1080/17565529.2013.830954

Thrift, N. (2008). Non-representational Theory: Space, Politics, Affect. London: Routledge. doi:10.4324/9780203946565

Tschakert, P., and Tuana, N. (2013). "Situated Resilience: Reframing Vulnerability and Security in the Context of Climate Change," in Climate Talk: Rights, Poverty and Justice. Editors F. Bray, J. Ferlay, I. Soerjomataram, R. L. Siegel, L. A. Torre, and A. Jemal South Africa: Juta and Company, 75-96.

Tschakert, P., van Oort, B., St. Clair, A. L., and LaMadrid, A. (2013). Inequality and Transformation Analyses: a Complementary Lens for Addressing Vulnerability to Climate Change. Clim. Dev. 5 (4), 340-350. doi:10.1080/17565529.2013.828583

Van Hecken, G., Kolinjivadi, V., Casolo, J., Abdulla, S., and Elliot Blomqvist, R. (2020). Towards a Non-extractive and Care-Driven Academia, .Available at: https://beyonddevelopment.net/towards-a-non-extractive-and-care-drivenacademy/ (Accessed 3108 2020).

Velicu, I., and García-López, G. (2018). Thinking the Commons through Ostrom and Butler: Boundedness and Vulnerability. Theor. Cult. Soc. 35 (6), 55-73. doi:10.1177/0263276418757315
Welsh, M. (2014). Resilience and Responsibility: Governing Uncertainty in a Complex World. Geographical J. 180 (1), 15-26. doi:10.1111/ geoj. 12012

Wijsman, K., and Feagan, M. (2019). Rethinking Knowledge Systems for Urban Resilience: Feminist and Decolonial Contributions to Just Transformations. Environ. Sci. Pol. 98, 70-76. doi:10.1016/j.envsci.2019.04.017

Conflict of Interest: The authors declare that the research was conducted in the absence of any commercial or financial relationships that could be construed as a potential conflict of interest.

Copyright (C) 2021 Gonda, Leder, González-Hidalgo, Chiwona-Karltun, Stiernström, Hajdu, Fischer, Asztalos Morell, Kadfak and Arvidsson. This is an open-access article distributed under the terms of the Creative Commons Attribution License (CC $B Y)$. The use, distribution or reproduction in other forums is permitted, provided the original author(s) and the copyright owner(s) are credited and that the original publication in this journal is cited, in accordance with accepted academic practice. No use, distribution or reproduction is permitted which does not comply with these terms. 